\title{
The small strain stiffness from bender elements tests for clayey soils
}

\author{
KATARZYNA MARKOWSKA-LECH ${ }^{1}$, WOJCIECH SAS ${ }^{1}$, MARIUSZ LECH ${ }^{2}$, \\ KATARZYNA GABRYŚ ${ }^{1}$, ALOJZY SZYMAŃSKI ${ }^{2}$ \\ ${ }^{1}$ Water Center Laboratory, Faculty of Civil and Environmental Engineering, Warsaw University of Life \\ Sciences - SGGW \\ ${ }^{2}$ Faculty of Civil and Environmental Engineering, Warsaw University of Life Sciences - SGGW
}

\begin{abstract}
The small strain stiffness from bender elements tests for clayey soils. The shear modulus of soils at small strain $\left(G_{0}\right)$ is one of the input parameters in a finite element analysis with the hardening soil model with small strain stiffness, required in the advanced numerical analyses of geotechnical engineering problems. The small strain stiffness can be determined based on the seismic wave velocities measured in the laboratory and field tests, but the interpretation of test results is still under discussion because of many different factors affecting the measurements of the wave travel time. The recommendations and proposed solutions found in the literature are helpful as a guide, but ought to be adopted with a certain measure of care and caution on a case-by-case basis. The equipment, procedures, tests results and interpretation analyses of bender elements (BE) tests performed on natural overconsolidated cohesive soils are presented.
\end{abstract}

Key words: small strain stiffness, bender elements, clays

\section{INTRODUCTION}

In recent years, there has been an increasing interest in describing the mechanical behaviour of soils at small strain. The shear modulus at very small strain $G_{0}$ (the initial shear modulus) is widely considered to be a fundamental property of the soil stiffness and is crucial in practical geotechnical solutions, particularly in the prediction of soil-structure interaction and earthquake engineering (LoPresti et al. 1999, Schneider et al. 1999, Pelli et al. 2004, Schinad 2005, Stokoe et al. 2005, Clayton 2011, Lipiński et al. 2017). Hardin and Black (1968) have identified the major factors contributing to the actual value of the shear modulus, such as vertical effective stress, void ratio, overconsolidation ratio $(O C R)$, soil fabric, temperature and the degree of saturation.

The initial shear modulus $\left(G_{0}\right)$ of the soil at induced strain levels less than $0.0001 \%$ can be obtained from the shear wave velocity using the following equation:

$$
G_{0}=\rho \cdot V_{S}^{2}
$$

where:

$\rho$ - mass density;

$V_{s}-$ shear waves velocity for linear, elastic and isotropic medium. 
The most developed techniques, which are represented by a combination of standard geotechnical tests with geophysical test module (shear wave velocity measurements), have been used both in the laboratory and in the field tests. Field techniques include the seismic cone penetration test, the seismic flat dilatometer, the crosshole test and the SASW. Laboratory tests include resonant column, torsional shear and triaxial shear tests with local strain measurement and bender element test (Schneider et al. 1999, Schnaid 2005). Those configurations diminish the disadvantages of each test group and significantly enhance the optimization of data collection (Wolski and Lipiński 2006). In our paper the results of bender element test performed on natural cohesive soils are presented.

Various methods have been studied for determining the travel time such as the first arrival time, the travel time between the characteristic points, and the cross-correlation method (Viggiani and Atkinson 1995, Brignoli et al. 1996, Jovicic el al. 1996, Arulantan et al. 1998,
Zeng and Ni 1999, Lee and Santamarina 2005, Leong at al. 2005, Yamashita et al. 2007, Chee-Ming 2012). As reported in the literature, there is still some uncertainty regarding the best method of shear wave arrival time definition, be it in the time or frequency. Although some other researchers have claimed that frequency domain methods are more reliable, visual picking of the arrival time in the time domain was found to be equally good, and had the advantage of being simpler and quicker (Chee-Ming 2012).

Nowadays, a bender element test is commonly used to measure the shear wave velocity in laboratory conditions. A piezoelectric bender element test is a relatively simple non-destructive test to measure shear and compression wave velocities and determine the shear modulus. But the number of different factors affecting the measurements of the travel time in the bender elements tests causes difficulties in choosing the reliable method of determination of the first arrival time and there is no standard method for this tests (Clayton 2011, Table 1).

TABLE 1. Variants in bender element testing (after Clayton 2011)

\begin{tabular}{|l|l|l|l|}
\hline Issue & \multicolumn{1}{|c|}{$\begin{array}{c}\text { Brief } \\
\text { description }\end{array}$} & \multicolumn{1}{|c|}{ Effect } & \multicolumn{1}{c|}{ Suggested standard } \\
\hline \multirow{3}{*}{$\begin{array}{l}\text { Bender } \\
\text { dimensions }\end{array}$} & $\begin{array}{l}\text { Width and } \\
\text { protrusion into } \\
\text { the specimen }\end{array}$ & $\begin{array}{l}\text { Travel distance is generally } \\
\text { accepted as bender tip-to- } \\
\text {-tip. Reduced travel distance } \\
\text { causes reduced accuracy. In- } \\
\text { stallation of highly protruding } \\
\text { bender elements is more diffi- } \\
\text { cult in specimens of stiff/hard } \\
\text { natural sediment }\end{array}$ & $\begin{array}{l}\text { Most laboratories adopt 10 mm width, } \\
0.5-1.0 \mathrm{~mm} \text { thickness, and a protru- } \\
\text { sion of }<5 \mathrm{~mm} \text {. Shorter protrusion } \\
\text { approx.1 mm) is favoured in the UK } \\
\text { when testing stiff natural materials, } \\
\text { where otherwise a slot needs to be cut } \\
\text { and the bender filled around during } \\
\text { instation. Fixing epoxy is set back } \\
\text { inside end caps, and the space filled } \\
\text { with silicone rubber compound, to al- } \\
\text { low flexing of the bender element }\end{array}$ \\
\hline
\end{tabular}


TABLE 1. cont.

\begin{tabular}{|c|c|c|c|}
\hline Issue & $\begin{array}{c}\text { Brief } \\
\text { description }\end{array}$ & Effect & Suggested standard \\
\hline $\begin{array}{l}\text { Bender } \\
\text { construction }\end{array}$ & $\begin{array}{l}\text { Transmitter } \\
\text { and receiver } \\
\text { bender con- } \\
\text { figurations, } \\
\text { extender } \\
\text { elements, and } \\
\text { self-monitor- } \\
\text { ing configura- } \\
\text { tions }\end{array}$ & $\begin{array}{l}\text { Using different (series and } \\
\text { parallel) bimorphs as trans- } \\
\text { mitter and receiver improves } \\
\text { shear wave generation and } \\
\text { reception. Extender elements } \\
\text { allow P-wave generation. Use } \\
\text { of a self-monitoring configu- } \\
\text { ration, allows the movement } \\
\text { of the bimorph (as distinct } \\
\text { from its driving voltage) to be } \\
\text { determined }\end{array}$ & $\begin{array}{l}\text { Experience suggests that the wiring of } \\
\text { benders as S-wave transmitters, } \\
\text { P-wave transmitters and S-wave re- } \\
\text { ceivers gives advantages. Self-moni- } \\
\text { toring bender elements may be useful, } \\
\text { as they allow the detection } \\
\text { of time lags and phase changes } \\
\text { between driving voltage and actual } \\
\text { movement of the transmitter, result- } \\
\text { ing from characteristic impedance } \\
\text { mismatch }\end{array}$ \\
\hline $\begin{array}{l}\text { Location } \\
\text { of bender } \\
\text { elements }\end{array}$ & $\begin{array}{l}\text { Bender ele- } \\
\text { ments may be } \\
\text { mounted in } \\
\text { the rigid base } \\
\text { and top caps } \\
\text { of cells, or } \\
\text { through the } \\
\text { triaxial mem- } \\
\text { brane }\end{array}$ & $\begin{array}{l}\text { Mounting across or along } \\
\text { specimens allows shorter } \\
\text { travel distances (giving } \\
\text { reduced attenuation and } \\
\text { higher } S / N \text { ratio), and deter- } \\
\text { mination of the velocity of } \\
\text { waves polarised in different } \\
\text { directions. Very-small strain } \\
\text { anisotropy of stiffness can } \\
\text { then be inferred from shear } \\
\text { wave velocities } \\
\end{array}$ & $\begin{array}{l}\text { The addition of side-mounted bender } \\
\text { elements is relatively easy to achieve } \\
\text { using grommets and O-rings similar } \\
\text { to those for mid-plane pore water } \\
\text { pressure measurement }\end{array}$ \\
\hline $\begin{array}{l}\text { Travel } \\
\text { distance }\end{array}$ & $\begin{array}{l}\text { Small tip-to- } \\
\text {-tip travel dis- } \\
\text { tance affects } \\
\text { travel time } \\
\text { resolution. } \\
\text { Large distance } \\
\text { increases at- } \\
\text { tenuation } \\
\end{array}$ & $\begin{array}{l}\text { Closely spaced benders dis- } \\
\text { play more scatter in calculat- } \\
\text { ed shear wave velocity. Data } \\
\text { from widely spaced benders } \\
\text { are more noisy. The estimated } \\
\text { travel time may be affected }\end{array}$ & $\begin{array}{l}\text { Calculated shear wave velocities may } \\
\text { be affected if large bender element } \\
\text { penetrations are used in conjunction } \\
\text { with small specimens. Higher trans- } \\
\text { mitter frequencies will be needed to } \\
\text { keep the wavelength down }\end{array}$ \\
\hline $\begin{array}{l}\text { Input wave } \\
\text { form }\end{array}$ & $\begin{array}{l}\text { Square, con- } \\
\text { tinuous sine } \\
\text { or pulsed sine } \\
\text { waves }\end{array}$ & $\begin{array}{l}\text { Square wave pulses contain } \\
\text { a broad spectrum of frequen- } \\
\text { cies. Low frequencies place } \\
\text { the receiver in the near field }\end{array}$ & $\begin{array}{l}\text { Practice suggests single sine pulses } \\
\text { produce acceptable traces, giving } \\
\text { repeatable first break or peak-to-peak } \\
\text { travel times, and permitting a more } \\
\text { restricted and controllable input } \\
\text { frequency }\end{array}$ \\
\hline $\begin{array}{l}\text { Input wave } \\
\text { mode }\end{array}$ & P- or S-wave & $\begin{array}{l}\text { In soft saturated soil P-waves } \\
\text { travel at approx.1,450-1,550 } \\
\mathrm{m} / \mathrm{s} \text { (the P-wave velocity } \\
\text { of water), much faster than } \\
\text { S-waves. In unsaturated soils } \\
\text { P-waves travel only approx. } \\
50 \% \text { faster, and can obscure } \\
\text { or be confused with S-waves }\end{array}$ & $\begin{array}{l}\text { It is suggested that extender elements } \\
\text { should be routinely used to warn of } \\
\text { misinterpretation }\end{array}$ \\
\hline
\end{tabular}


TABLE 1. cont.

\begin{tabular}{|c|c|c|c|}
\hline Issue & $\begin{array}{c}\text { Brief } \\
\text { description }\end{array}$ & Effect & Suggested standard \\
\hline $\begin{array}{l}\text { Input } \\
\text { frequency }\end{array}$ & $\begin{array}{l}\text { Low source } \\
\text { frequencies } \\
\text { produce long } \\
\text { wavelengths }\end{array}$ & $\begin{array}{l}\text { Long wavelengths place the } \\
\text { receiver in the near field, af- } \\
\text { fecting the received wave- } \\
\text { form and picked travel time }\end{array}$ & $\begin{array}{l}\text { The receiver should be at least } \\
2-3 \text { wavelengths from the transmit- } \\
\text { ter. It is suggested that, for routine } \\
\text { triaxial testing, results are returned for } \\
\text { a range of frequencies from about } 2.5 \\
\text { to } 12.5 \mathrm{kHz} \text { ) }\end{array}$ \\
\hline $\begin{array}{l}\text { Data acquisi- } \\
\text { tion }\end{array}$ & $\begin{array}{l}\text { Low voltage } \\
\text { and temporal } \\
\text { resolution } \\
\text { reduce quality } \\
\text { of captured } \\
\text { traces }\end{array}$ & $\begin{array}{l}\text { Picked arrival times become } \\
\text { uncertain }\end{array}$ & $\begin{array}{l}\text { In order that accuracy is not degraded } \\
\text { by resolution. the sampling time } \\
\text { interval should be less than } 1 \mathrm{st} / 100 \text { th } \\
\text { of the travel time between transmit- } \\
\text { ter and receiver. Voltage resolution } \\
\text { should be better than } 1 \text { st } / 100 \text { th of the } \\
\text { amplitude of the received signal }\end{array}$ \\
\hline $\begin{array}{l}\text { Signal-to- } \\
\text {-noise ratio }\end{array}$ & $\begin{array}{l}\text { Noise affects } \\
\text { low-ampli- } \\
\text { tude received } \\
\text { signals }\end{array}$ & $\begin{array}{l}\text { Picking of first arrival or peak } \\
\text { times is subjective. A low } \\
\text { signal-to-noise ratio increases } \\
\text { scatter and tends to increase } \\
\text { the estimated travel time }\end{array}$ & $\begin{array}{l}\text { A study of some relatively noisy UK } \\
\text { data suggests a minimum amplitude } \\
\text { signal/noise ratio }(S / N) \text { as of } 10 . \\
\text { Leong et al. (2005) suggest a receiver } \\
S / N \text { ratio of at least } 4 \mathrm{~dB}\end{array}$ \\
\hline $\begin{array}{l}\text { Method of } \\
\text { determining } \\
\text { travel time }\end{array}$ & $\begin{array}{l}\text { First-break, } \\
\text { peak-to-peak, } \\
\text { cross-correla- } \\
\text { tion, or phase/ } \\
\text { /frequency } \\
\text { relationship }\end{array}$ & $\begin{array}{l}\text { Different processing methods } \\
\text { lead to different travel times. } \\
\text { With mixed frequencies pulse } \\
\text { broadening may occur, owing } \\
\text { to attenuation of the higher- } \\
\text { frequency component, lead- } \\
\text { ing to increases in measured } \\
\text { travel time when using peak- } \\
\text { to-peak detection. Receiver } \\
\text { first breaks may be hidden by } \\
\text { noise, leading to increases in } \\
\text { measured travel time when } \\
\text { using this method }\end{array}$ & $\begin{array}{l}\text { First-break and first-peak-to-first- } \\
\text {-peak travel time detection are } \\
\text { favoured by Yamashita et al. (2007), } \\
\text { who found significant differences in } \\
\text { some cases where cross-correlation } \\
\text { and phase/frequency methods were } \\
\text { used. It is suggested that results from } \\
\text { both the first break and the peak-to- } \\
\text {-peak methods be routinely reported }\end{array}$ \\
\hline
\end{tabular}

\section{MATERIALS AND METHODS}

The triaxial shear tests presented in this paper were performed in a cell with internal linking bars, which enables easy access to the sample at each stage of its preparation, and equipped with the bender elements at the top and the bottom platen. This type of cell also provides more reliable deformation characteristics in the consolidation and shearing stage of the test. The bender elements were inserted in the soil samples during the triaxial shear tests. The change in voltage applied to the transmitter causes it to bend and transmit a shear wave through the sample; the arrival of the shear wave at the other end of the sample is recorded by the receiver as a change in voltage (Viggiani 1995, Brignoli et al. 1996, Ka- 


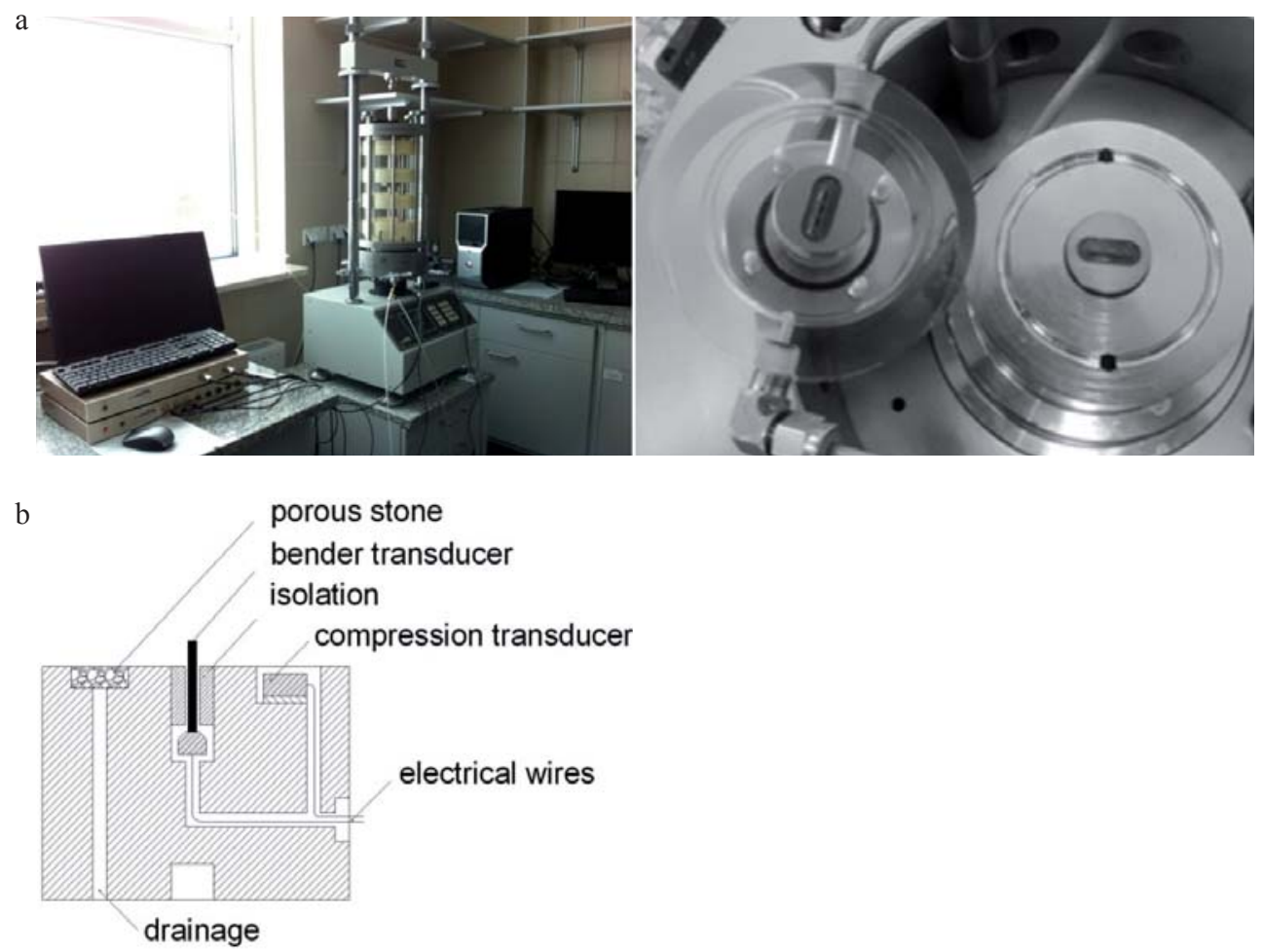

FIGURE 1. Research stand in the Laboratory - Water Center WULS-SGGW equipped with GDS Instruments devices (A division of Global Digital Systems Ltd); a - the bender elements at the top and the bottom platens of triaxial apparatus; $b$ - schematic draw of triaxial base with bender element configuration (Brignoli et al. 1996)

waguchi et al. 2001). The bender element test setup is shown in Figure 1.

The methods of the interpretation of the arrival time of the shear wave can be classified into two main groups: the time-domain methods and the frequency-domain methods. In the time domain, the user visually determines the arrival time of the shear wave by examining the output and input signal voltages versus time. In the frequency domain, the input and output signals are transformed in the frequency domain (Vilhar and Jovicic 2009). Both groups of interpretation methods were focused on minimizing the influence of the dispersion and near-field effects.

The tested samples were taken from two test sites. The first one is a small village located to the south of Warsaw, at the experimental site of Warsaw University of Life Sciences. The results of the field tests (boreholes, CPT and DMT tests) and the laboratory tests showed that the stratigraphy consists of the Quaternary deposits including moraine clays and sandy clays (Markowska-Lech et al. 2016, Table 2). The free groundwater table is at a depth of about $2.0 \mathrm{~m}$. The second location is Stegny, the southern district of Warsaw with 
TABLE 2. Index properties of tested clays (Markowska-Lech et al. 2016)

\begin{tabular}{cccccccc}
\hline Sample & Soil & $\begin{array}{c}\text { Depth } \\
(\mathrm{m})\end{array}$ & $\begin{array}{c}F C^{*} \\
(\%)\end{array}$ & $\begin{array}{c}w_{n} \\
(\%)\end{array}$ & $\begin{array}{c}P I \\
(\%)\end{array}$ & $\begin{array}{c}L I \\
(-)\end{array}$ & $\begin{array}{c}\rho \\
\left(\mathrm{t} / \mathrm{m}^{3}\right)\end{array}$ \\
\hline 1 & sandy clay & $0.9-4.0$ & $11-15$ & $9.7-16.7$ & $17.6-23.9$ & $-0.1-0.20$ & 2.1 \\
\hline 2 & clay & $4.0-12.0$ & $4-11$ & $11.9-15.9$ & $2.99-20.4$ & $0.05-0.20$ & 2.05 \\
\hline 3 & clay & $4.3-7.7$ & $68-80$ & $26-34$ & $52.6-76.4$ & $0.14-0.23$ & $2.0-2.1$ \\
\hline 4 & silty clay & $7.7-8.9$ & $30-34$ & $19-25$ & $39.3-55.6$ & $0.04-0.22$ & $2.0-2.4$ \\
\hline 5 & clay & $8.9-12$ & $32-46$ & $19-27$ & $61.9-84.0$ & $0-0.005$ & $2.0-2.1$ \\
\hline
\end{tabular}

*Clay content $(<0.002 \mathrm{~mm})$.

a stratigraphy including the Quaternary deposits developed as fine and medium density sand layers with the thickness of up to $4.5 \mathrm{~m}$, underlain by the overconsolidated Pliocene clays. The clay beds feature a clear-layered structure with layers in different colours. The free groundwater table is at a depth of $3.2 \mathrm{~m}$ (Lech et al. 2009, Markowska-Lech and Bajda 2016).
The laboratory tests were carried out on 13 undisturbed clay and sandy clay samples and included: general index tests for classification and characterization of the clay, density, grain size distribution and measurement of shear wave velocity. The samples contained undisturbed natural Quaternary moraine clay and sandy clay (S1-S8) deposits and the lacustrine

TABLE 3. Index properties of soil samples tested in the triaxial tests

\begin{tabular}{|c|c|c|c|c|c|}
\hline Sample & $\begin{array}{c}\text { Depth } \\
(\mathrm{m})\end{array}$ & $\begin{array}{c}F C^{*} \\
(\%)\end{array}$ & $\begin{array}{c}w_{n} \\
(\%)\end{array}$ & $\begin{array}{c}\rho \\
\left(\mathrm{t} / \mathrm{m}^{3}\right)\end{array}$ & $\begin{array}{c}e_{0} \\
(-)\end{array}$ \\
\hline S1 & $1.2-1.7$ & 11 & 12.9 & 2.17 & 0.392 \\
\hline S2 & $2.0-2.5$ & 15 & 13.3 & 2.12 & 0.430 \\
\hline S3 & $4.0-4.2$ & 12 & 12.2 & 2.10 & 0.430 \\
\hline S4 & $4.2-4.8$ & 12 & 12.2 & 2.24 & 0.343 \\
\hline S5 & $5.0-5.5$ & 13 & 10.6 & 2.30 & 0.286 \\
\hline S6 & $5.8-6.3$ & 13 & 11.4 & 2.24 & 0.331 \\
\hline S7 & $6.5-7.0$ & 4 & 11.2 & 2.24 & 0.331 \\
\hline S8 & $7.8-8.5$ & 11 & 11.4 & 2.25 & 0.325 \\
\hline S9 & 6.5 & 68 & 21.8 & 2,08 & 0,595 \\
\hline S10 & 7.75 & 60 & 22.1 & 2,0 & 0,657 \\
\hline S11 & 8.5 & 29 & 20.4 & 1,84 & 0,784 \\
\hline S12 & 9.0 & 36 & 32.1 & 1,86 & 0,929 \\
\hline S13 & 9.95 & 63 & 27.9 & 1,90 & 0,833 \\
\hline
\end{tabular}

*Clay content $(<0.002 \mathrm{~mm})$. 
deposits of the Pliocene clay (S9-S13), retrieved using a Shelby sampler from the depths between 1.2-7.8 $\mathrm{m}$ (S1-S8) and 6.5-9.95 $\mathrm{m}$ (S9-S13), respectively. The tested soil samples were characterized as follows: water content $w_{n}$ from 10.6 to $32.1 \%$, liquidity index $(L I)$ from 26.5 to $88.1 \%$, plastic limit $P L$ from 9.9 to $32.2 \%$, plasticity index $(P I)$ from 14.8 to $60.6 \%$, and clay content $(F C)$ from 4 to $68 \%$. In Table 3 the physical properties of all tested samples are summarized.

\section{LABORATORY TESTS AND RESULTS}

In this study, the triaxial shear tests were performed on 13 undisturbed clay samples in three stages: saturation (backpressure method), consolidation and shearing (strain-controlled mode at strain rate of $0.005 \mathrm{~mm} / \mathrm{min}$ ). The samples were consolidated in an isotropic stress condition. Shear wave velocity was measured at the end of each of saturation and consolidation stages during the triaxial shear tests. The single sine waves with frequencies of $1-10 \mathrm{kHz}$ were used as an input signal. The shear wave velocity $\left(V_{s}\right)$ was calculated from the ratio of the tip-to-tip distance (Viggiani and Atkinson 1995) between the transmitter and the receiver, using the following relationship:

$$
V_{s}=h / t
$$

where:

$h$-distance between the transmitter and the receiver geophones (the effective wave travel path through the sample); $t$ - travel time of seismic waves between the transmitter and the receiver.
The initial shear modulus was calculated from Equation (1). The initial arrival time of the shear wave to the receiver $\left(R_{d}\right)$ can be affected by the near-field effect disturbances, described by the formula:

$$
R_{d}=h / \lambda=\left(h f_{\text {in }}\right) / V_{s}
$$

where:

$h$ - effective wave travel length (m);

$\lambda$ - wave length (m);

$f_{\text {in }}-$ input signal frequency $(\mathrm{Hz})$.

If the ratio of the distance to wavelength $\left(R_{d}\right)$ is greater than 2 , it has been perceived that the near-field effect can be ignored when the shear wave is measured. However, it can be seen that in the case of a medium with $5 \%$ material damping the arrival of the shear wave is marked by a smooth slope, not a sharp slope, even though $R_{d}$ is greater than 4 , while the shear wave presents a clear arrival with no damping. This is due to coupling of the shear wave and near-field wave. The initial arrival of the shear wave is located near the bump when $R_{d}$ is 0.5 and moves in the direction of the first peak of the shear wave with an increase in $R_{d}$. Therefore, it is difficult to determine the travel time reliably from the first arrival of the shear wave. On the other hand, if the travel time is calculated using the time between the first peaks of the input and received waves, error in the travel time is less than $2 \%$ when $R_{d}$ is greater than 2 (Youn et al. 2008).

Figures 2 and 3 show the traces obtained in bender element tests on sample S10 with different $R_{d}$ values from 0.52 to 4.10 which correspond in this case 

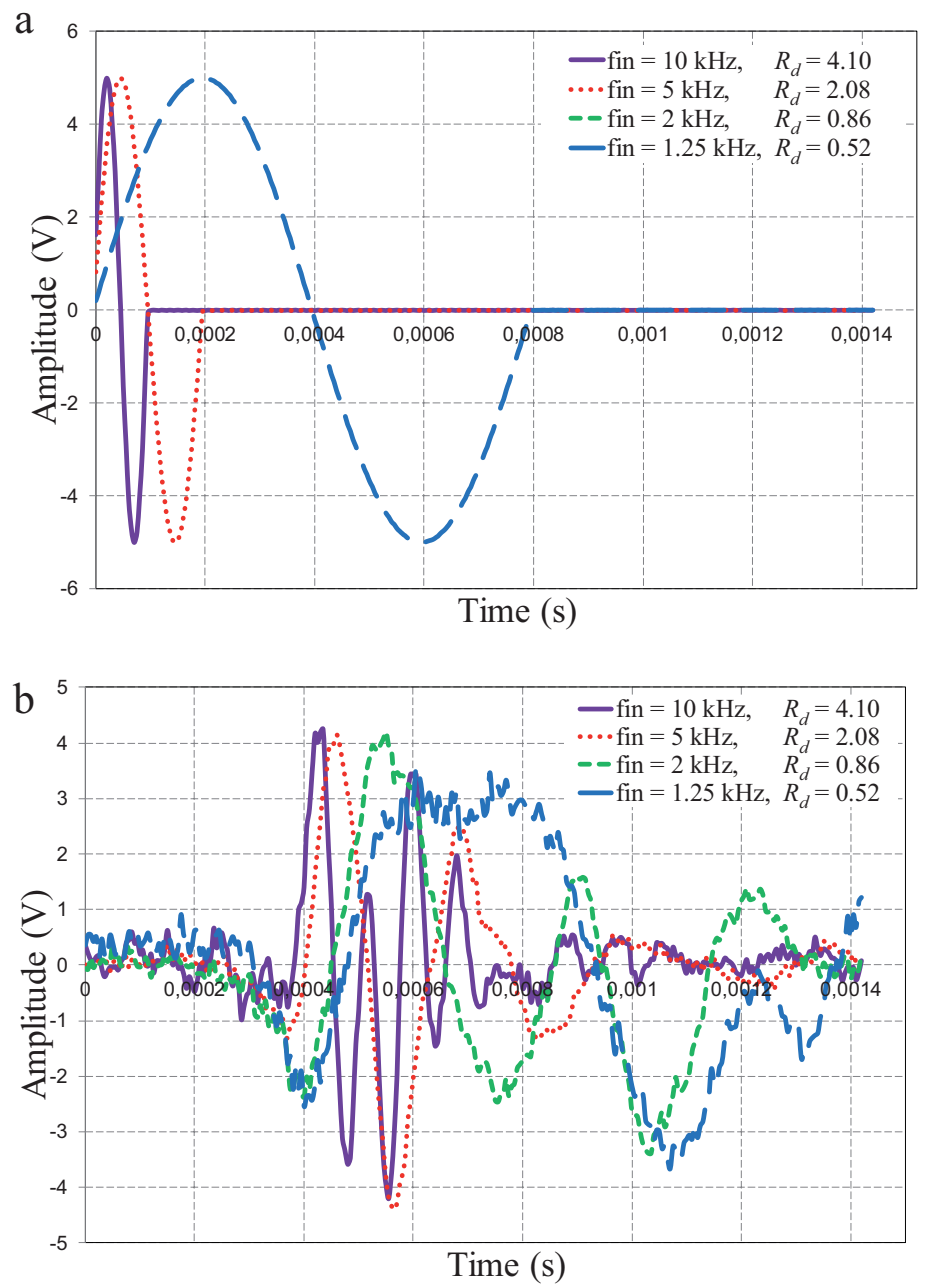

FIGURE 2. Example waveforms four signals with different wave lengths and values of $R_{d}$ obtained in bender element tests on natural clays (sample S10; mean effective stress equal to $930 \mathrm{kPa}$; (a) transmitted signals, (b) received signals

to frequencies from 1.25 to $10 \mathrm{kHz}$, respectively. The time scale has been normalized with respect to the arrival time of the shear wave determined by visual peak-to-peak method. For low values of $R_{d}$ there is an initial downward deflection of the trace before the shear wave arrives, representing the near-field effect. At higher $R_{d}$ the near-field effect is much smaller, almost absent. In tested soil samples, the input signals with $R_{d}<$ $<1$ do not usually produce a readable output. On the other hand, high frequency inputs did not always produce the best output; sometimes it was impossible to identify the arrival time.

Figure 4 presents the test results performed on sample S10 that show the 

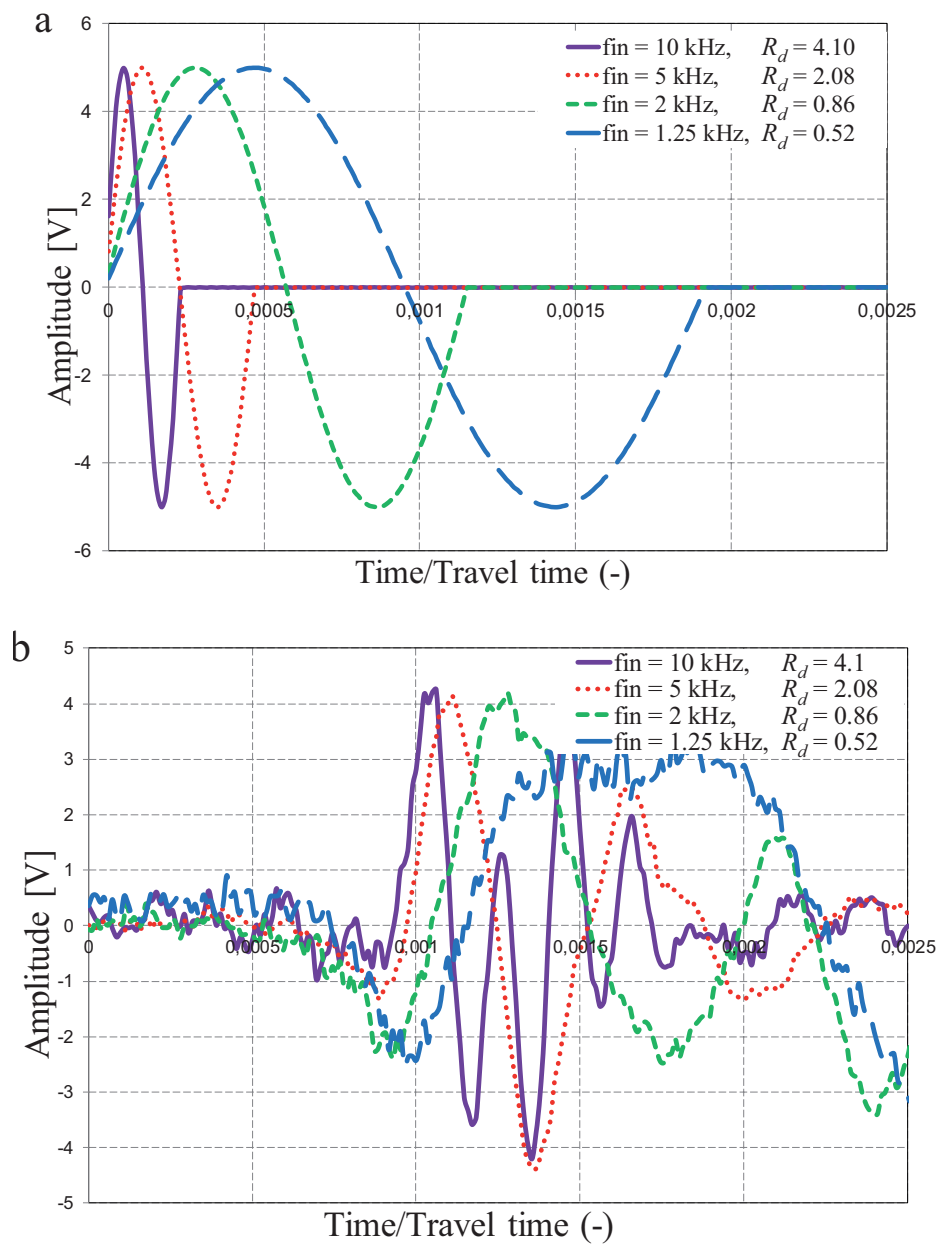

FIGURE 3. Example waveforms four signals with different wave lengths and values of $R_{d}$ obtained in bender element tests on natural clays (sample S10, mean effective stress equal to $930 \mathrm{kPa}$ ); the time scale has been normalized with respect to the arrival time of the shear wave determined by peak-to-peak method; (a) transmitted signals, (b) received signals

influence of the transmitted signal frequency from 1.25 to $10 \mathrm{kHz}$ on shear wave velocity (the arrival time was determined by the peak-to-peak method). The shear wave velocity increases with increasing of the mean effective stress for different frequencies of the input signal. The relationship between the shear wave velocity and the input signal fre- quency cannot be clearly determined: the highest values of the shear wave velocity were obtained for transmitted signal frequency of $10 \mathrm{kHz}$ irrespective of the mean effective stress level, the lowest values of the shear wave velocity were obtained for input signal frequency of $1.25 \mathrm{kHz}$ at mean effective stress of $155 \mathrm{kPa}$ only and for transmitted signal 


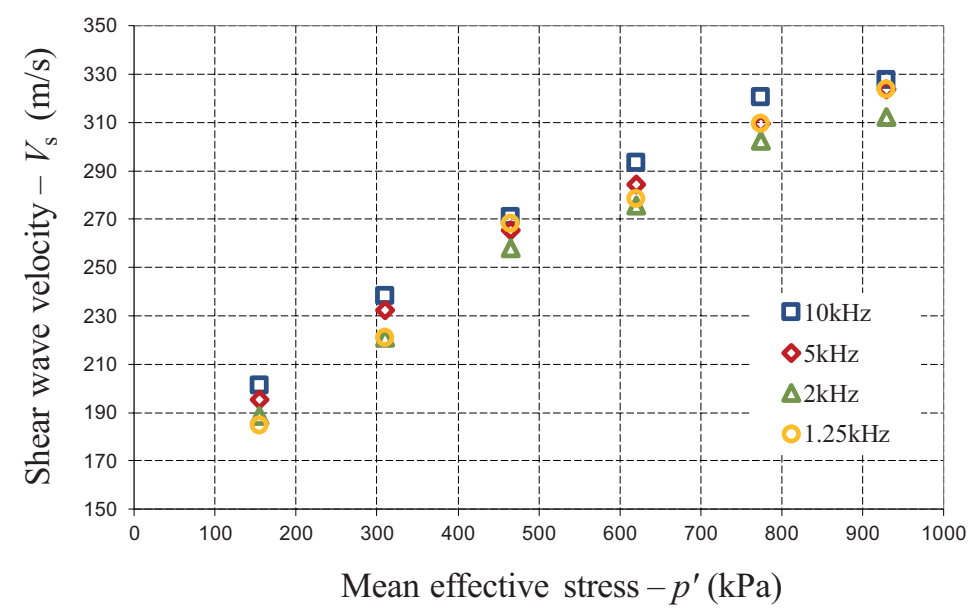

FIGURE 4. The influence of the transmitted signal frequency on shear wave velocity (peak-to-peak method; sample S10)

frequency of $2 \mathrm{kHz}$ in others stress level. In the case of the mean effective stress of $310 \mathrm{kPa}$, the shear wave velocity equal $216 \mathrm{~m} / \mathrm{s}$ for both lowest transmitted signal frequency: 1.25 and $2 \mathrm{kHz}$.

There are several different approaches in identifying the arrival time of the shear wave. The first one is by observing the transmissed and received wave signal and finding their difference as a propagation time in the soil specimen. Since this method uses a time base axis in order to identify the propagation's time, it is often called the time domain technique (TD). With this method, the arrival time of the shear wave is affected by the near-field-effect disturbances, the influence of the compression wave signals and other electric noises and reflections etc. It often makes the reading of arrival time quite difficult (Yamashita et al. 2007, Sas et al. 2015, Sas et al. 2016).

Viggiani and Atkinson (1995) compared different first arrivals of the received signal at different potential points. Point $A$ is the first deflection; point $B$ is the first inflection (first bump maximum); point $C$ is the first zero after inflection (zero crossing); and point $D$ is the second inflection (Fig. 5).

These methods depend on a visual determination of the first major positive departure of the received signal from zero amplitude; they can only be used if the received signal is clear and remains flat before the first deflection. A better method than the visual picking of the first deflection point may be

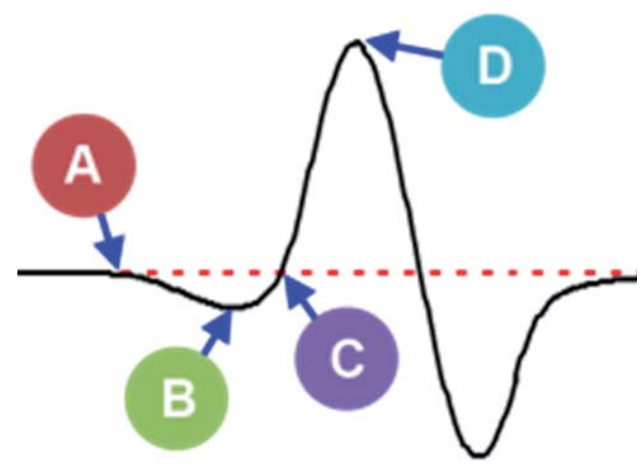

FIGURE 5. Potential arrival points (after Viggiani and Atkinson 1995) 
the first major peak-to-peak method. It compared the time between the first two major peaks of the transmitted and the received signals. This method is not affected by the distortion of the received signal or by the near-field effects, but it requires good quality of the signals.

Another way is to calculate the arrival time on the basis of the time (time domain) or frequency (frequency domain) axis. The cross-correlation $(C C)$ between the transmitted and the received wave is based on the presumption that the transmitted shear wave retains its wave shape, i.e. frequency even when it is passed into the soil. In this method, the $C C$ of transmitted and the received wave is first evaluated and the position at the maximum amplitude is taken as the propagation time. However, there are times when frequencies of transmitted and received waves do not agree and the second peak or the next one at the received wave, rather than the first one, becomes larger in amplitude. Further- more, as this method calculates arrival time using the time base axis, it is often said to be identical to the $T D$. The second method calculates the cross spectrum of the transmitted and the received waves producing the relations of the amplitude and phase angle with frequency axis. The arrival time is then calculated from the inclination of the phase spectrum. As it uses the frequency characteristics of input and output waves, it is often called the frequency domain technique (FD) (Yamashita et al. 2007). In both method, an experienced researcher with a proper knowledge how to interpret the correlated result is needed and there is a subjective aspect to this testing technique.

In Figure 6 and Table 4 the results of determination of the shear wave velocity from bender element test using different analysis method at different arrival points performed on the sample S10 at the mean effective stress of $930 \mathrm{kPa}$ and the input signal frequency of $5 \mathrm{kHz}$ are

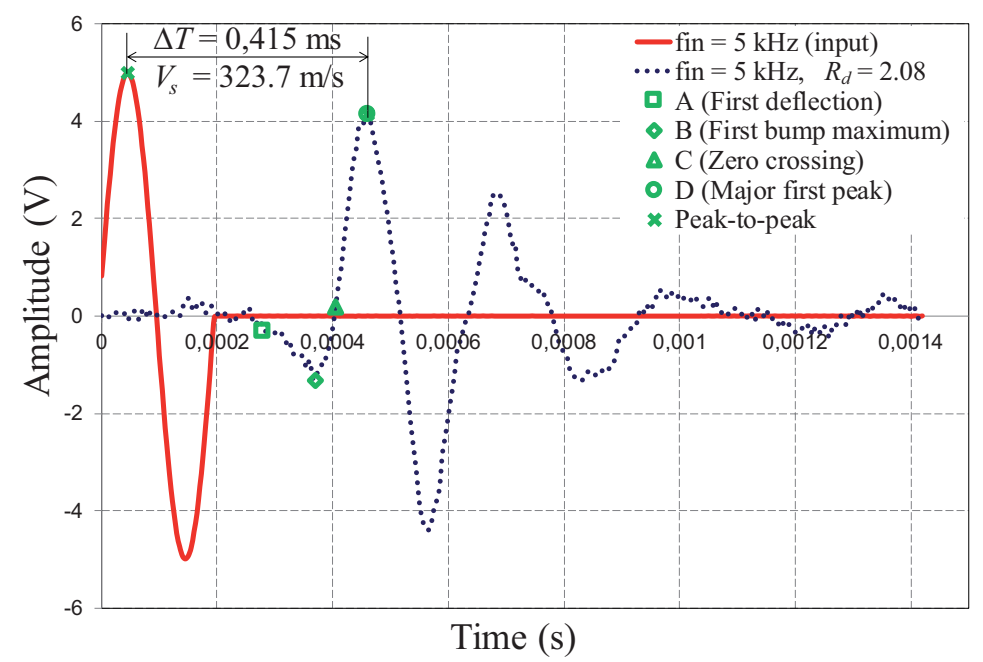

FIGURE 6. Different method of the travel time identification (sample S10, mean effective stress equal to $930 \mathrm{kPa}$, input signal frequency equal to $5 \mathrm{kHz}$ ) 
TABLE 4. Determination of the shear wave velocity using different analysis method (sample S10, mean effective stress equal to $930 \mathrm{kPa}$, input signal frequency equal to $5 \mathrm{kHz}$; the arrival time in point $A, B$, $C, D$ and $T D, F D$ was read automatically by the $G D S$ software)

\begin{tabular}{|l|c|c|c|}
\hline Analysis method / arrival point & $\begin{array}{c}\text { Travel time } \\
(\mathrm{ms})\end{array}$ & $\begin{array}{c}\text { Shear wave velocity } \\
(\mathrm{m} / \mathrm{s})\end{array}$ & $\begin{array}{c}\Delta V_{s} \\
(\mathrm{~m} / \mathrm{s})\end{array}$ \\
\hline$A$ & 0.280 & 479.8 & 156.1 \\
\hline$B$ (first bump maximum) & 0.370 & 363.1 & 39.4 \\
\hline$C$ (zero crossing) & 0.405 & 292.1 & -31.7 \\
\hline$D$ & 0.460 & 323.70 & 0 \\
\hline Peak-to-peak & 0.415 & 319.90 & -3.9 \\
\hline Cross-correlation $(T D)$ & 0.405 & 319.90 & -3.9 \\
\hline Frequency domain $(F D)$ & 0.405 & 331.7 & 0 \\
\hline
\end{tabular}

shown. The tests results from different methods have been compared to the results from the visual picking method, which is so far the simplest, the most direct and the least time-consuming method.

In Figure 7 the relationship between the shear wave velocity and the mean effective stress from different analysis method i.e. peak-to-peak, the previous different arrival points namely point $A$ (the first deflection), point $B$ (the first inflection - first bump maximum), point $C$ (the first zero after inflection - zero crossing) and point $D$ (the second inflection) and $T D$ (cross-correlation - time domain) and $F D$ (frequency domain) obtained at the input signal frequency of $1.25,2$ and $5 \mathrm{kHz}$ is presented. The results show the largest differences in the values of the shear wave velocity at the input signal frequency of $1.25 \mathrm{kHz}$ (Fig. 7a), which indicate an uncertainty of the measurements at low input frequency, regardless of the mean effective stress level during the next consolidation stage. The example of input signal frequency of $10 \mathrm{kHz}$ (Fig.7d), show that the results obtained from point $B$ and $C$ method are irregularly distributed and the results from $A$ method could not be determined; this indicates a significant disturbance of the received signal. The smallest differences in values of the shear wave velocity were obtained at the higher input frequency in peak-to-peak, point $C$, the $T D$ and the $F D$ methods independently from the mean effective stress level. Sometimes received signal makes it impossible to identify the arrival time of shear wave velocity.

In Figures 8-11 the laboratory test results for the bender element tests, namely the relationship between the shear wave velocity, mean effective stress and void ratio, are displayed. The shear wave velocity varies from 150 to $420 \mathrm{~m} / \mathrm{s}$ for sample $\mathrm{S} 1-\mathrm{S} 8$ from the first test site and from 100 to $320 \mathrm{~m} / \mathrm{s}$ 

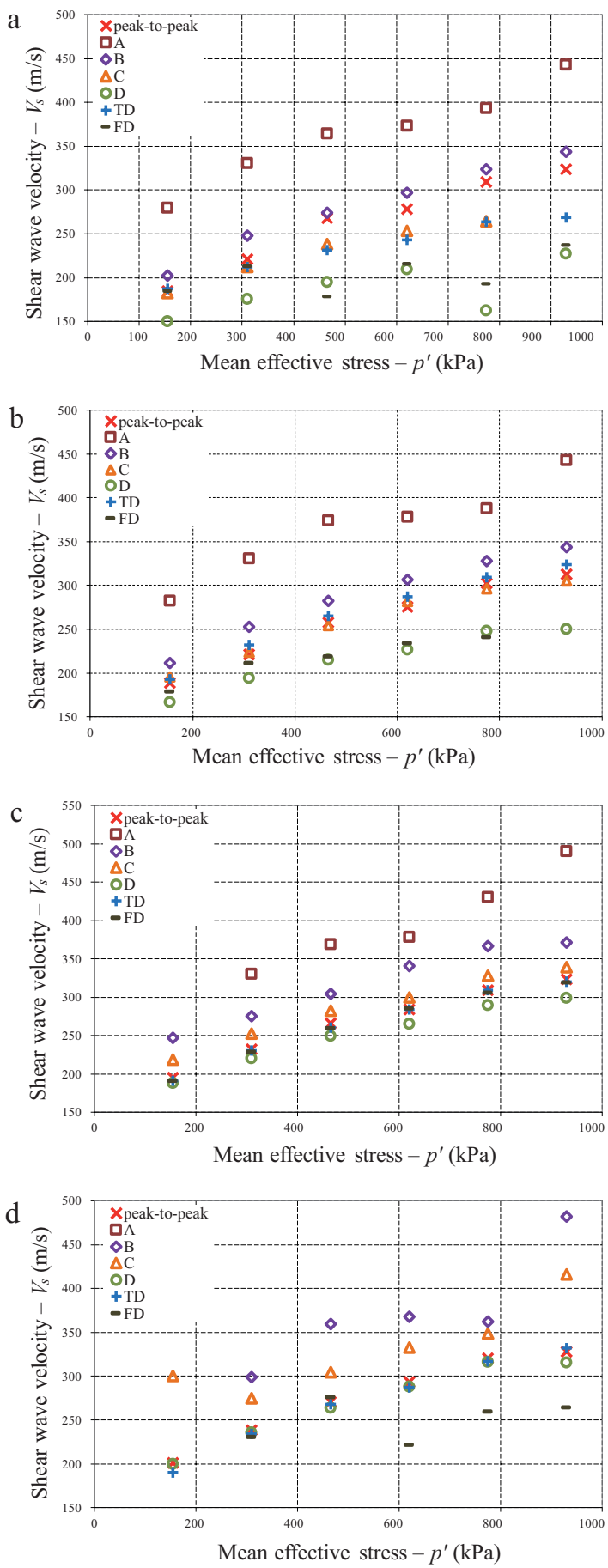

FIGURE 7. Shear wave velocity vs. mean effective stress from different analysis method: a - input signal frequency $1.25 \mathrm{kHz} ; \mathrm{b}$ - input signal frequency $2 \mathrm{kHz} ; \mathrm{c}$ - input signal frequency $5 \mathrm{kHz} ; \mathrm{d}$ - input signal frequency $10 \mathrm{kHz}$ (sample $\mathrm{S} 10$; the arrival time in point $A, B, C, D$ and $T D, F D$ was read automatically by the GDS software) 
for sample S9-S13 from Stegny test site within the mean effective stress range between 15 and $1,000 \mathrm{kPa}$. An increase in the mean effective stress during the next consolidation stage decreases the void ratio and as a result increases the shear wave velocity. In Figure 10 a visible difference between the shear wave velocity for soils derived from the first (samples $\mathrm{S} 1-\mathrm{S} 8$ ) and the second (S9-S13) tests sites can be noticed due to different contents of clay fraction in the soil specimens. For the first group of the specimens the increase of shear wave velocity is faster and it achieves higher values than for the second group. The highest increase in the shear wave velocity is observed for sample S8 from the first test site and the lowest is observed for sample S12 from Stegny site. A similar relationship can be observed in Figures 12-14; the increase of the shear modulus at small strain is faster and it achieves higher values in the first group of soil speci- mens (S1-S8) in comparison with the second group. The shear modulus $G_{0}$ presented in Figures 12-14, calculated using the elastic theory from equation (1) reaches the values from about 50 to $400 \mathrm{MPa}$ for deposits from the first test site and from 50 to $220 \mathrm{MPa}$ for clays from Stegny site.

Virtually horizontal lines drown between the obtained data for individual specimens in Figures 8-14 indicate the changes in stress, which affect the shear wave velocity (and the shear modulus) to a lesser degree in high plasticity soil.

The values of the shear wave velocity and the shear modulus at small strain $\left(G_{0}\right)$ obtained using bender elements techniques are lower than those obtained from the field tests (Markowska-Lech et al. 2016). To sum up, the soil stiffness values obtained in the field tests are expected to be higher than the values obtained from the laboratory tests due to the possible disturbance of the soil specimens.

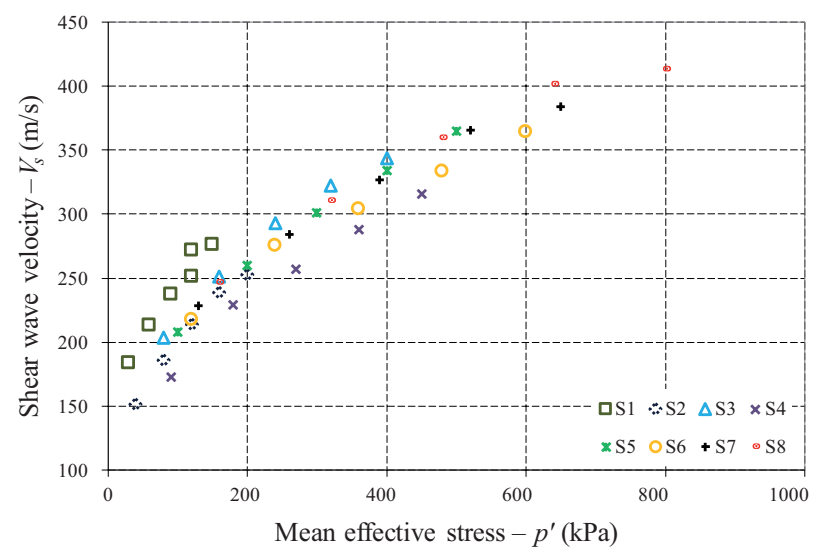

FIGURE 8 . Shear wave velocity in clays vs. mean effective stress based on laboratory tests (S1-S8 samples) 


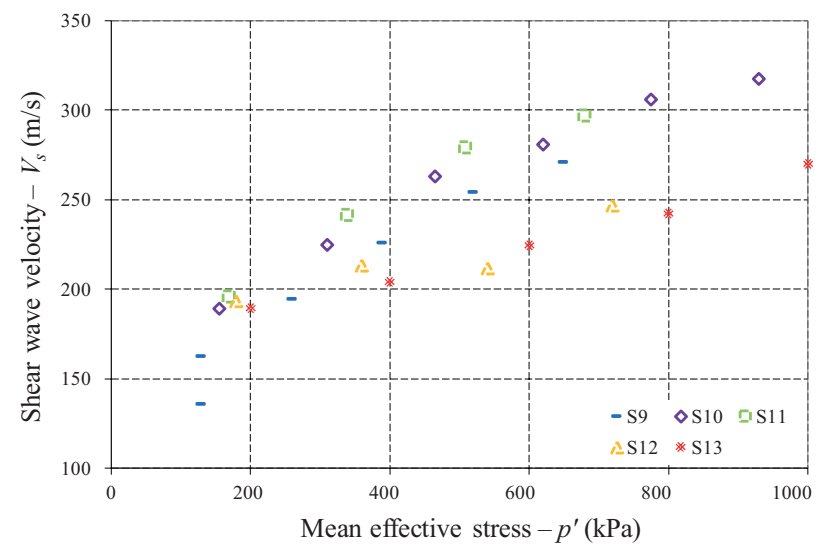

FIGURE 9. Shear wave velocity in clays vs. mean effective stress based on laboratory tests (S9-S13 samples)

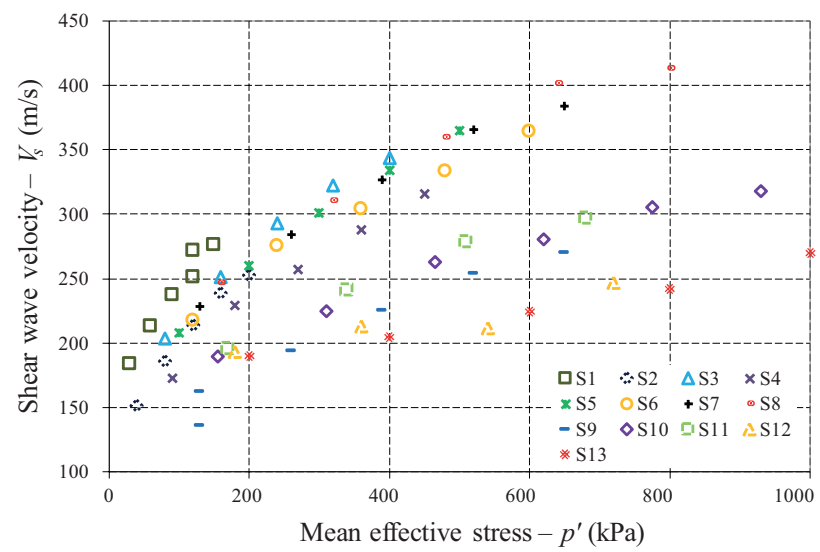

FIGURE 10. Shear wave velocity in clays vs. mean effective stress based on laboratory tests (S1-S13 samples)

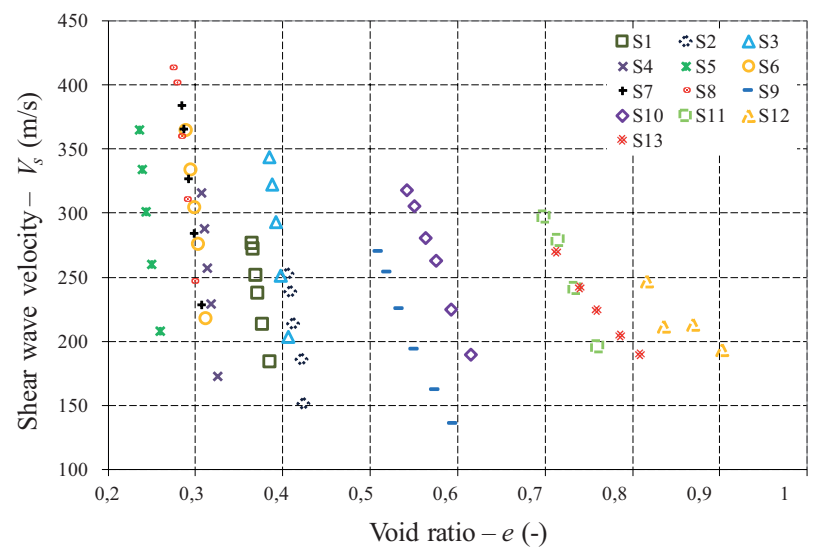

FIGURE 11. Shear wave velocity in clays vs. void ratio based on laboratory tests (S1-S13 samples) 


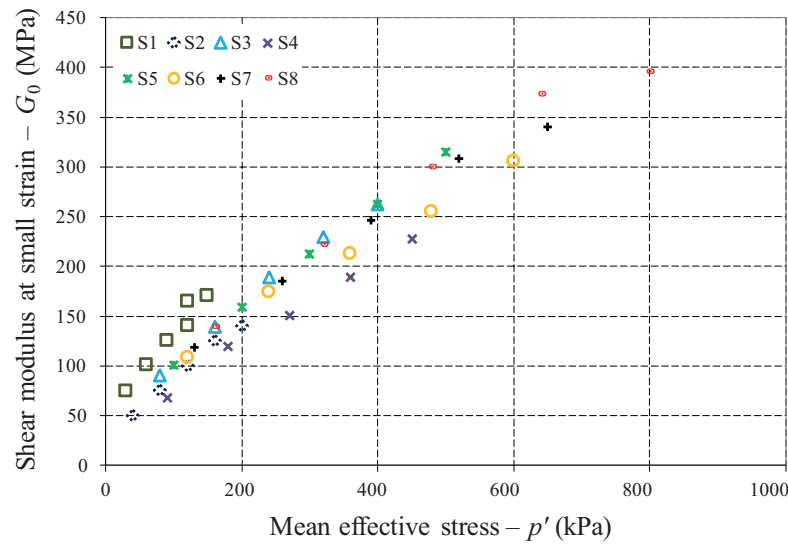

FIGURE 12. Shear modulus for clays based on laboratory tests (S1-S8 samples)

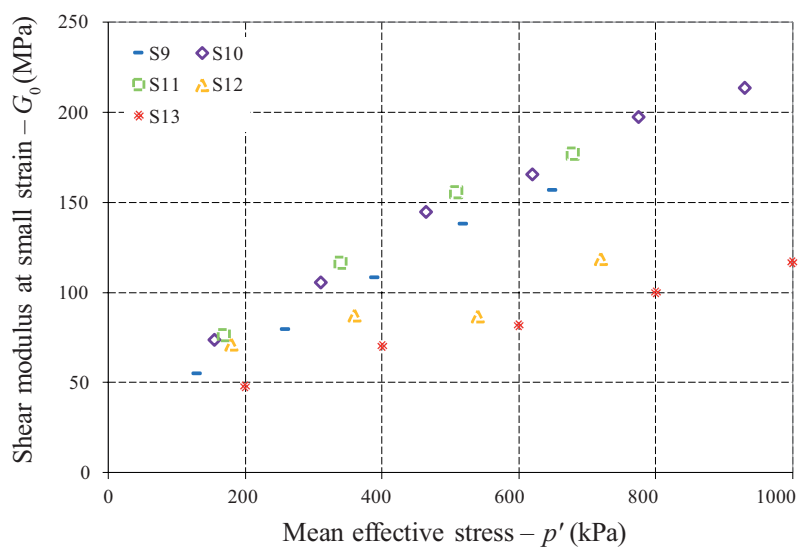

FIGURE 13. Shear modulus for clays based on laboratory tests (S9- S13 samples)

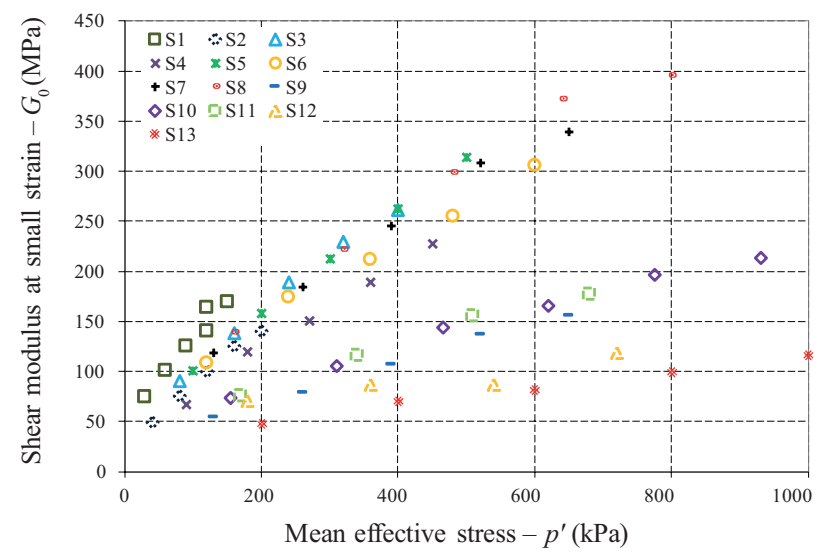

FIGURE 14. Shear modulus for clays based on laboratory tests (S1-S13 samples) 


\section{CONCLUSIONS}

The following conclusions can be drawn from presented experimental results:

- The input frequency range given by $R_{d}>1$ readable output is likely, the upper range may be decided from the visibility of the received signal; in the tested specimens, higher input did not always produce the best signal.

- In every method for identification of the arrival time of the shear wave, an experienced researcher with a proper knowledge how to interpret the correlated result is necessary; there is a subjective aspect to this testing technique; there is available an automatic system for the travel time estimation process, but it still requires technician control.

- The mean effective stress and the void ratio significantly affect the shear wave velocity in the tested soils; there is a linear relationships between the mean effective stress and the shear wave velocity at a very small strain.

- Despite a high correlation between the shear wave velocity and the mean effective stress and the void ratio for tested soils, the investigation must be continued to establish the influence of stress history on the shear modulus, in particular in highly overconsolidated cohesive soils.

\section{Acknowledgements}

This research was funded by the National Science Centre, Poland (contract 0467/B/T02/2011/40).

\section{REFERENCES}

ARULANTAN R., BOULANGER R.W., RIEMER M.F. 1998: Analysis of bender element tests. Geotech. Test. J. 21 (2): 120-131.

BRIGNOLI E., GOTTI M., STOKOE K.H. II 1996: Measurement of shear waves in laboratory specimens by means of piezoelectric transducers. ASTM Geotech. Test. J. 19 (4): 384-397.

CHEE-MING Ch. 2012: Variations of Shear Wave Arrival Time in Unconfined Soil Specimens Measured with Bender Elements. Geotech. Geol. Eng. 30: 461-468. DOI:10.1007/s10706-011-9480-3

CLAYTON C.R.I. 2011: Stiffness of small strain: research and practice. Géotechnique 61 (1): 5-37.

HARDIN B.O., BLACK W.L. 1968: Vibration modulus of normally consolidated clay. J. Soil Mech. Found. Div. ASCE 94 (2): 353-368.

JOVICIC V., COOP M.R., SIMIC M. 1996: Objective criteria for determining $\mathrm{G}_{\max }$ from bender element tests. Géotechnique 46 (2): 357-362.

KAWAGUCHI T., MITACHI T., SHIBUYA S. 2001: Evaluation of shear wave travel time in laboratory bender element test. In: Proceedings of 15 th International Conference on Soil Mechanics and Geotechnical Engineering, Istanbul, Vol. 1: 155-158.

LECH M., BAJDA M., MARKOWSKA-LECH K. 2009: The use of resistivity and seismic cone penetration tests for site characterization. Ann. Warsaw Univ. Life Sci. - SGGW. Land Reclam. 40 (1): 87-96.

LEE J-S., SANTAMARINA C. 2005: Bender elements: performance and signal interpretation. J. Geotech. Geoenviron. Eng. 131 (9): 1063-1071.

LEONG E.C., YEO S.H., RAHARDJO H. 2005: Measuring shear wave velocity using bender elements. Geotech. Test. J. 28 (5): 488-498. DOI: 10.1520/GTJ12196 
LIPIŃSKI M.J., WDOWSKA M.W., JAROŃ J. 2017: Shear wave velocity for evaluation of state of cohesionless soils with fines. IOP Mat. Sci. Eng. 245, \#032083. DOI: $10.1088 / 1757$ $-899 X / 245 / 3 / 032083$

LOPRESTI D.C.F., PALLARA O., JAMIOLKOWSKI M., CAVALLARO A. 1999: Anisotropy of small stiffness of undisturbed and reconstituted clays. In: R.J. Jardineet al. (Eds.), Pre-failure Deformation of Geomaterials. Balkema, Rotterdam: 3-10.

MARKOWSKA-LECH K., BAJDA M. 2016: Wyznaczanie modułu odkształcenia postaciowego $\mathrm{G}_{0} \mathrm{w}$ iłach [Estimation of shear modulus $\mathrm{G}_{0}$ for clays]. Sci. Rev. Eng. Env. Sci. 71: 3-12.

MARKOWSKA-LECH K., SAS W., GABRYŚ K., BAJDA M., LECH M. 2016: Determination of the small strain stiffness of selected cohesive soils from Warsaw, Poland. In: 16th International Multidisciplinary Scientific Geoconference SGEM 2016, Albena, Book 1, Vol. 3: 77-84.

PELLI F., MINUTO D., ISETTA E., LOMBARDI G. 2004: Geotechnical characterization of an overconsolidated Pliocene clay by field and laboratory tests. In: Proceedings ISC-2 on Geotechnical and Geophysical Site Characterization. Millpress, Rotterdam: 1827-1834.

PN-EN ISO 14688:2006. Badania geotechniczne. Oznaczanie i klasyfikowanie gruntów [Geotechnical investigation and testing. Identification and classification of soil].

SAS W., GABRYŚ K., SZYMAŃSKI A. 2015: Effect of Time on Dynamic Shear Modulus of Selected Cohesive Soil of One Section of Express Way No. S2 in Warsaw. Acta Geoph. 63 (2): 398-413. DOI: 10.2478/s11600-014-0256-Z

SAS W., GABRYŚ K., SOBÓL E., SZYMAŃSKIA. 2016: Dynamic Characterization of Cohesive Material Based on Wave Velocity Measurements. Appl. Sci. 6 (2): 49. DOI: 10.3390/app6020049
SCHNAID F. 2005: Geo-characterization and properties of natural soils by in situ tests. In: Proceedings of the 16th International Conference on Soil Mechanics and Geotechnical Engineering, Osaka. Millpress, Rotterdam: 3-45.

SCHNEIDER J.A., HOYOS L. Jr, MAYNE P., MACARI E.J., RIX G.J. 1999: Field and laboratory measurements of dynamic shear modulus of Piedmont residual soils. ASCE Geotechnical Special Publication 92: 12-25.

STOKOE K.H II, RATHJE E.M., AXTELL P.J. 2005: Development of an in situ method to measure the nonlinear shear modulus of soil. In: Proceedings of the 16th International Conference on Soil Mechanics and Geotechnical Engineering, Osaka. Millpress, Rotterdam: 751-754 .

VIGGIANI G. 1995: Panelist discussion: Recent advances in the interpretation of bender element tests. In: Pre-failure Deformation of Geomaterials. Balkema, Rotterdam, Vol. 2: 1099-1104.

VIGGIANI G., ATKINSON J.H. 1995: Interpretation of bender element tests. Géotechnique 45 (1): 149-154.

VILHAR G., JOVICIC V. 2009: Measurement and interpretation of the small strain stiffness of Bostanj silty sand. Acta Geotech. Slov. 2: 57-75.

WOLSKI W., LIPINSKI M.J. 2006: Site characterization for geotechnical and environmental purposes. In: Proceedings of the 13th Danube-European Conference on Geotechnical Engineering, Ljubljana, Vol. 1: 129-150.

YAMASHITA S., FUJIWARA T., KAWAGUCHI T., MIKAMI T., NAKATA Y., SHIBUYA S. 2007: International parallel test on the measurement of $\mathrm{G}_{\max }$ using bender elements. Retrieved form: http:// www.jiban.or.jp/e/tc29/BE_Inter_PP_ Test_en.pdf.

YOUN J-U., CHO O-W., KIM D-S. 2008: Measurement of small-strain shear modulus $G_{\max }$ of dry and saturated sands by bender element, resonant column, and 
torsional shear tests. Can. Geotech. J. 45: 1426-1438. DOI: 10.1139/T08-069

ZENG X., NI B. 1999: Stress-induced anisotropic $G_{\max }$ of sands and its measurement. J. Geotech. Geoenviron. Eng. 125 (9). DOI: 10.1061/(ASCE)10900241(1999)125:9(741)

Streszczenie: Sztywność gruntów spoistych wakresie matych odksztatceń z badań wykorzystujacych piezoelementy typu bender. Moduł odkształcenia postaciowego $G_{0}$ jest jednym z kluczowych parametrów w modelach sprężysto-plastycznych gruntu ze wzmocnieniem koniecznym w numerycznych analizach zagadnień współpracy konstrukcji z gruntem. Parametr ten może być wyznaczany na podstawie prędkości fal mechanicznych rozchodzacych się w gruncie, mierzonych $\mathrm{w}$ badaniach laboratoryjnych $\mathrm{i}$ terenowych. Pomimo popularności tych badań problemem pozostaje interpretacja wyników pomiaru czasu przejścia fali przez próbkę gruntu, wynikająca z dużej liczby czynników wpływających na sztywność gruntu oraz na sam pomiar. Propozycje rozwiązań, które można znaleźć w literaturze, mogą służyć jedynie jako wskazówki do interpretacji konkretnego przypadku pomiaru. W artykule przedstawione zostały wyniki oraz interpretacja badań wykonanych na naturalnych gruntach spoistych z wykorzystaniem aparatu trójosiowego wyposażonego w piezoelementy typu bender.

Slowa kluczowe: sztywność gruntu w zakresie małych odkształceń, piezoelementy typu bender, grunty spoiste

MS received 30.10.2018

MS accepted 28.12.2018

\section{Authors' address:}

Mariusz Lech

Wydział Budownictwa i Inżynierii Środowiska

Szkoła Główna Gospodarstwa Wiejskiego

w Warszawie

ul. Nowoursynowska 159, 02-776 Warszawa

Poland

e-mail: mariusz_lech@sggw.pl 